\title{
Practice and Exploration on the Training Mode of Cooperation Talents of Local Undergraduate Colleges in Jilin Province
}

\author{
LIU Shu ${ }^{1, a}$, QIAN Yuzhuo ${ }^{2, b}$ \\ ${ }^{1}$ College of Mechanical Engineering, Baicheng Normal University, Baicheng,137000, China \\ ${ }^{2}$ College of Economics and Management, Baicheng Normal University, Baicheng,137000, China \\ aemail:2493301@qq.com, bemail:8438136@qq.com
}

Keywords: Local Colleges, Cooperation between schools and enterprises, Personnel Training, Practical Exploration

\begin{abstract}
The local colleges in the process of cultivating talents, mode is difficult to adapt to the demand of the social development of the traditional training, talent training scheme is relatively backward, personnel quality is not high, there is not much and the needs of society, these are largely restricts the employment rate and the social recognition of local undergraduate. The local colleges in the process of cultivating talents, should actively carry out in-depth cooperation and effective. The school should realize to improve the talent quality through the cooperation between school and enterprise ,to fully optimize the level of talent through the cooperation between school and enterprise, to realize the talent ' s counterpart culture through the school - enterprise cooperation.
\end{abstract}

\section{Introduction}

Local colleges and universities are the main position of talent training. With the promotion of the national enrollment expansion policy, the students of local colleges and universities have been effectively expanded, and some local colleges and universities have set up colleges and universities. It is also gradually upgraded to a university, which has been effectively expanded in terms of educational funds, school size, number of majors, number of students, etc. With the development of higher education in our country, it has entered the stage of mass education. As a local, comprehensive, teaching-oriented school, local undergraduate colleges have gradually become the main force of undergraduate education in higher education in China, but local colleges and universities in the process of talent training. Based on the limitations of their own professional development and the weakness of the advantage resources, it restricts the level and quality of talent training. Based on this, in the process of talent training in local colleges and universities. We should actively explore the talent training mode of cooperation between schools and enterprises, and let enterprises participate in the training of talents from the point of view of the actual needs of talents[1].

\section{The Value Analysis of Training the Talents of School Enterprise Cooperation in Local Colleges and Universities}

In the process of personnel training, local undergraduate colleges and universities can effectively avoid the limitation of their professional development, can effectively avoid the weakness of their own professional advantages, and also can comprehensively improve the cultivation level of the talents and comprehensively optimize the cultivation quality of the talents .

Optimizing the Social Adaptability and Demand of Talents. In the process of talent output , local undergraduate colleges have a great disconnect between the professional accomplishment and professional skills and social demand of talents. The enterprises are the main places for talent reception . They are in urgent need of the practical , practical and high - quality talents who are " able to fight and win ". At present, they have no obligation to continue to cultivate talents . At the same time, the university students who graduated from local universities are suffering from social criticism[2]. At the present stage, the enterprise faces a large gap of talents, and the university 
students are hard to get employment quickly, which is undoubtedly a serious waste of social resources .Based on this, in the process of local university talents cultivation, should actively explore and use the way of school enterprise cooperation. In the process of cultivating talents in local colleges, not behind closed doors, no longer using a fixed set of teaching contents, but combined with the actual needs of enterprises, combined with the needs of enterprises, professional personnel corresponding training needs of enterprises. Through the cooperation between school and enterprise of science, the school can be actively carried out the optimization in teaching content, through the cooperation of science, the school can clear training direction. Therefore, in the process of local university talents cultivation, through the cooperation between school and enterprise of science, can ease the contradiction between the demand of enterprises and the personnel training, personnel practice effectively cultivate social needs, ease the contradiction of talent shortage, the optimization of social resources, comprehensive scientific promotion Steady party economic development, talent reserve regional prosperity in science[3].

The only Way for the Development of the Campus Culvert in the Local Undergraduate College. Local colleges and universities in the rapid development process, although has received a lot of educational input and social attention, but due to the undergraduate running a short time, teachers are relatively weak, social awareness is not high. Insufficient accumulation of teaching investment restricts the quality of practical talents cultivation in local colleges and universities. Only the cooperation of school and enterprise, the combination of production, learning and research can improve the quality of talents. Local colleges and universities in the process of talent training. To get rid of the traditional "closed door building" talent training mode, actively adopt the "go out, bring in" scientific talent training model, fully combined with the needs of enterprises, targeted to improve the quality of talent training. On the one hand, through the cooperation of science, personnel training schools have to practice base, it can enhance students' practical literacy, which itself can cultivate comprehensive talent quality optimization. Local colleges and universities in the training process, due to lack of funds, limited resources, teaching time is not long, it is difficult to have an independent, professional and practical base. This makes the local colleges often theory accomplishment is very good, but the practice ability is generally low. Through cooperation, by the enterprise to provide for the students practice platform, which itself can enhance students' comprehensive quality. On the other hand, the cooperation based on science, but also helps to optimize the teachers' comprehensive qualities. The theoretical teaching ability at the present stage of local colleges a line teachers generally have higher, but the lack of practice teaching skills. Through the cooperation between school and enterprise and it helps to build the "double" teachers. In the cooperation, students can have a place and practice of resource rich practice, teachers can also get the corresponding training. It helps to optimize the professional quality of teachers and promote the overall improvement of teachers' teaching skills[4].

Giving full Play to the Service Radiation Ability of Local Undergraduate Colleges. In the process of talent training in local colleges and universities, through scientific cooperation between schools and enterprises, we can give full play to the ability of service radiation of local colleges and universities, and comprehensively promote the in-depth development of local colleges and universities. Promote the healthy development of the local economy in a comprehensive and effective way. In the process of setting up local colleges and universities, it is important to serve the local economic development and to radiate the local economic development, although the local colleges and universities are in the process of recruiting students. We will appropriately increase the number of students from other places, but in fact, the source of students in local colleges and universities is still dominated by this city[5]. Local graduates of local colleges and universities will choose local employment in the process of employment and career selection. Based on this, through school enterprise cooperation, local colleges through further cooperation with local enterprises, can be fully combined with the actual needs of enterprises, and constantly promote the quality of personnel training, and constantly improve the level of personnel training, to fully meet the requirements of the development of talent, fully meet the requirements of the development of enterprises. The cooperation of science, the school can be combined with the enterprise at this stage 
of the actual needs and future development direction, adjust the personnel training objectives, appropriate update the teaching contents, optimizing teaching efforts to update teaching ideas, promote the development of talents. If local universities than the area where coal is a heavy industry base, then the students in the College of chemistry and materials science and mineral processing major talent scheme, should increase the direction of coal chemical industry. Practice has proved that the cooperation of science, both at school, or to the enterprise, is a kind of "double Win ". Local universities can improve the employment rate, can improve the quality of personnel training, enterprises can get professional talents of high quality counterparts, fully meet the sustainable development of enterprises. Therefore, local colleges and universities in the process of cultivating talents, should make full use of school enterprise cooperation mode, deepening the cooperation level.

\section{Practice and Exploration on the Training Mode of the Cooperation of University - Enterprise Cooperation in Local Universities}

In the process of talents training of colleges and universities in local universities, it is necessary to rely fully on the dual advantages of local universities and enterprises, realize the integration of dominant resources, optimize the talents training program scientifically, and comprehensively improve the quality of personnel training . Based on this, to improve the cooperation of school enterprise cooperation, it is necessary to actively construct the talents training mode of school enterprise cooperation, and fully and comprehensively improve the quality of personnel training .

Building up the Long-term Development Cooperation Talent Training Mechanism of School-enterprise Cooperation. In the process of cooperation between schools and enterprises, because did not form a stable bilateral relations, is just a common practice in students' practice protocol, which makes the quality of school enterprise cooperation can not be effectively guaranteed. Based on this, to enhance the quality of school enterprise cooperation, Fang Benke of colleges and universities in the process of seeking business cooperation and coordination in must pay attention to the following. First, the process of local colleges in the school enterprise cooperation personnel training, should strengthen the research of local enterprises, local enterprises to fully understand the needs of local enterprises to fully grasp the talent gap. Combined with the actual situation, appropriate adjustment and integration of local colleges education resources, updating teaching content, timely supplement of the latest and most complete teaching policy. Secondly, the process of local colleges in the school enterprise cooperation personnel training, should be fully combined with the needs of enterprises, fully consider the actual interests of enterprises, a comprehensive scientific analysis the actual needs of enterprises, will respect the development of enterprises. On this basis, the willingness to enhance bilateral cooperation, but also to strengthen the good relations of cooperation. Finally, in the process of cooperation in local universities and enterprises should form a stable cooperative relations, to carry out in-depth cooperation from many aspects, to stabilize cooperation the relationship from many aspects, the content of cooperation agreement to determine the way down, the mechanism of school enterprise cooperation in personnel training to build long-term development, to enhance the overall level of cooperation[6].

Deepening Cooperation between Schools and Enterprises and Actively Developing Practice bases outside Schools. In the process of seeking cooperation between schools and enterprises, local universities should closely combine the development needs of enterprises, and deepen the strength and width of school enterprise cooperation, and constantly enhance the level of school enterprise cooperation. On the one hand, local colleges and universities in the process of in-depth cooperation with enterprises, should actively carry out the activities of professional construction. This is out of step with the actual needs of enterprises, but also makes local colleges and universities in the cultivation of talents, appear more mechanized. Therefore, to carry out effective cooperation between schools and enterprises, through the rational development of professional co-construction projects. Can give full play to the subjective initiative of schools and enterprises. In the process of professional co-construction, schools and enterprises to jointly formulate a talent training policy, 
together to determine the talent training program. Based on this, the talents trained in local colleges and universities can truly meet the actual needs of enterprises, and can truly meet the needs of society. Also can train the practical talents that the society needs truly, promote the professional accomplishment of the talented person in an all-round way. On the other hand, in the process of school-enterprise cooperation, as one of the cultivation side, enterprises should integrate their own advantage resources, integrate their own post needs, and provide abundant practice base for college talents. Effectively expand the practice base outside the school. Enterprises have a wealth of posts, these positions can become the main place of student practice. In the process of school-enterprise cooperation, we should try to avoid the process of practical practice content. We should improve the effectiveness of practice to ensure the normal production process.

Build a Perfect and Scientific Interactive Platform of Teaching and Research. In the process of cooperation between colleges and enterprises, the exploration and construction of the talents training model of cooperation between colleges and enterprises of local universities should also focus on improving the overall quality of teachers, and optimizing the professional competence of teachers . Based on this, in the process of cooperation between colleges and enterprises, we should try to build up a scientific research and teaching interactive platform .On the one hand, in the process of cooperation, local colleges should regularly invite enterprise front-line experts, technicians go to schools to practice experience to scientifically guide students to fully meet the needs of students in professional development. These experts or scholars, they themselves belong to the backbone of the enterprise, they are well versed in the enterprise development together, they know how professional needs of enterprise post. Therefore, invite them to participate in school lectures, guidance, counseling, students sort out the future direction of professional development to help with their own work experience, not only helps to promote the all-round development of students, but also help to guide the students to clear the professional development needs of the actual demand according to the positions of the enterprises to grow their own. On the other hand , in the process of cooperation between colleges and enterprises, local undergraduate colleges should also recommend the teachers in the school to penetrate into the enterprise and participate in the skill training and post training of the enterprises. Through such a bilateral interaction, the teachers who can truly enrich these theories can get out of the campus, walk out of the classroom , go to the enterprise , and carry out functional exercises in the enterprises .For an enterprise, it is also an egoistic thing for teachers to receive training and education in their positions. Enterprises can use abundant teachers to carry out staff training work. Emphasis on the training of theoretical literacy and professional literacy of staff, effectively improve the level of professional skills. In addition, through the establishment of interactive platforms, can train the ranks of university teachers, but also will be new knowledge of enterprises. Skills are applied to teaching practice to promote the development of students in an all-round and scientific way.

\section{Conclusion}

Local colleges and universities have weak teachers, limited running conditions and lack of practical teaching resources. In the process of talent training, it is difficult to effectively improve the professional quality of talents, and can not train social needs of applied talents. Based on this, in the process of talent cultivation in local colleges and universities, we should actively carry out school-enterprise cooperation, through in-depth and effective cooperation between schools and enterprises, to comprehensively improve the professional literacy of talents, and comprehensively optimize the professional skills of talents. Continue to train applied talents.

\section{Acknowledgement}

In this paper, the research was sponsored by the Educational Science Project of Jilin province during "13th Five-Year Plan” in 2017 (No. GH170587). 


\section{References}

[1]WANG Junfei. Exploration and practice of the training mode of college enterprise cooperative talents in Applied Undergraduate Colleges[J], Enterprise Reform and Management,2016 (6):217-217.

[2]WANG Yang, WU Yan, REN Guoling. The Practice and Exploration of the Training Mode of School Enterprise Cooperation Talents in Local Applied Undergraduate Colleges and Universities -Taking Daqing Normal University as an example[J],Education Teaching Forum,2017(12):157-158.

[3]LIU Zheng. Exploration on the Training Mode of School-Enterprise Cooperative Talents in Local Applied undergraduate Colleges-Take Logistics Management as an Example[J],Higher Education Exploration,2017(3):41-44.

[4]ZHANG Tao, SUN Haining, ZHEN Zhen. Practice and Reflection on the Training Mode of University-Enterprise Cooperation Personnel Training in Applied Undergraduate Colleges[J], Education, 2015(8):77-77.

[5]CHEN Guang, WEI Chunshi, ZHANG Haohui. Exploration and Practice of the Training Mode of College Enterprise Cooperative Talents in Applied Undergraduate Colleges[J],Journal of Heilongjiang Vocational Institute of Ecological Engineering,2011(6):67-68.

[6]LI Yanying, YU Chunxiao, HOU Yonghai. Exploration on the Training Mode of Cooperative Personnel Training for the Automation Major of Applied Undergraduate Colleges[J],Contemporary Education Research and Teaching Practice,2014(9):139-139. 